\title{
The Anatomy of the Stem of Macrozamia compared with that of other genera of Cycadeae ${ }^{1}$.
}

\author{
BY
}

W. C. WORSDELL.

With Plates XXVII and XXVIII.

COMPARATIVELY few investigations have hitherto been made into the minute anatomical structure of the stem of the Cycadeae; and any thorough and full account of this structure has been almost exclusively confined to two or three genera, as Cycas, Encephalartos, and Stangeria. Hence the examination of the stem of Macrozamia, a genus hitherto apparently untouched, seemed to promise some interesting: results.

\section{Historical SURvey.}

One of the oldest references to the internal structure of Cycadean stems is the investigation by Brongniart ${ }^{2}$; this work is consequently by no means free from erroneous interpretations. For example, the author entirely fails to recognize the presence of any phloem ('liber') in either of the two zones which he describes and figures in Cycas revoluta,

${ }^{1}$ From the Jodrell Laboratory, Royal Gardens, Kew.

${ }^{2}$ Recherches sur l'organisation des tiges des Cycadées, Ann. Sci. Nat. I, sér. XVI, I829.

[Annals of Botany, Vol. X. No. XL. December, 1896.] 
concluding that wood only is formed in this stem. His paper, however, is interesting and valuable, from the fact that he was the first to point out the real gymnospermous character of these stems and to refute the old idea of the similarity of their structure to that of Monocotyledons.

Von Mohl, in his paper 'Ueber den Bau des Cycadeenstammes ${ }^{1}$, gives a considerable amount of detail about the structure of the stems of Cycas and two species of ' $Z$ amia' ( $Z$. latifolia and $Z$. horrida). He states that in the pith of his Zamia latifolia there are a number of reticulately-united bundles, with scalariform or bordered pits, which pass singly through a medullary ray to the cortex. On the subject of anomalous thickening he says, speaking of Cycas, that some bundles from the normal ring pass out and run downwards through the cortex, arranging themselves side by side to form a second outer ring, of which, in 'Zamia', there are only very inconspicuous traces. It should be stated, however, that the plants called by him Zamia, are now placed by modern botanists under the genus Encephalartos ${ }^{2}$.

In the monograph by $\mathrm{Miquel}^{3}$ some of the anatomical characteristics of several genera are briefly touched upon, mention being made of such points as the nature of the pith, the pittings on the tracheides of the wood, \&c.

In the work on the Cycads by Mettenius ${ }^{4}$, which may perhaps be considered the best hitherto published, a great deal more light is thrown on the whole structure, and we are enabled to see very much more clearly how matters really stand with regard to the anatomy of these plants. It is from this paper that we have obtained most of our knowledge about Cycadean stems. He treats of the structure of Cycas revoluta,

1 Abh. der k. b. Acad. zu München, I, I $83_{2}$; republished and revised in Vermischte Schriften, 1845 .

${ }^{2}$ See v. Mohl, loc. cit., Verm. Schriften, p. I98, foot-note. His 'Zamia latifolia' was an African Encephalartos, and had nothing to do with the true Z. latifolia, Loddiges.

${ }^{3}$ Monographia Cycadearum, 1842.

${ }^{4}$ Beiträge zur Anatomie der Cycadeen, Abh. der K. Sächs. Gesellsch. der Wiss., VII, I86I. 
compared with other genera of Cycadeae. 603

Encephalartos horridus, Dioon edule, and Zamia muricata. In the two latter genera he finds no anomalous structure present.

Costantin and Morot ${ }^{1}$, who investigated Cycas siamensis, with regard to the structure of the pericycle, state that it is in this tissue that the anomalous rings have their origin.

Count Solms-Laubach ${ }^{2}$ has investigated the stem-structure

- of Stangeria paradoxa. The chief part of the paper is taken up with an elaborate description of the course of the ring of vascular bundles from the peduncle, which traverse the pith of the main stem for some distance before joining on to its vascular system. In this plant he finds no trace of any anomalous secondary thickening. The whole structure, with the exception of the medullary position of the cylinder from the peduncle, which is a phenomenon occurring also in other Cycads, is straightforward and normal.

Strasburger ${ }^{3}$, in his work on the vascular tissues, gives an accurate account of our present knowledge of the anatomy of Cycas, but so far as the stem is concerned has not extended his investigations to other genera.

\section{General Structure.}

The chief peculiarity in Cycadean stems, which was recognized and described by former writers, is the presence of anomalous rings of secondary thickening outside the normal zone. This character, however, has hitherto been described for two genera only, viz. Cycas and Encephalartos; other genera, as Zamia, Dioon, and Stangeria, are said to be without this abnormality. The genus Macrozamia has apparently not yet been investigated.

Having had the opportunity of examining an old stem of Macrozamia Fraseri, Miq., of more than one foot in diameter, grown at Kew, I was able to determine that the same anomaly

1 Bulletin de la Société Botanique de France, XXXII, I 885.

2 'Die Sprossfolge der Stangeria und der übrigen Cycadeen,' Bot. Zeitung, I890.

${ }^{3}$ Hist. Beiträge, III, p. I5I, I89I. 
which occurs in the stems of Cycas and Encephalartos is also to be found in the stem of this plant, though somewhat less marked here than in the above two genera.

The following are the main facts of the general structure :There is a large pith occupying half the diameter of the stem. Outside this is the normal vascular ring, consisting of about equal thicknesses of wood and bast. Immediately outside this is a similar ring of the same thickness, constituting the first anomalous zone. Immediately following this again is a third ring, consisting of very much smaller and more widely separated segments or bundles. This third ring is finally succeeded by a fourth series of segments, which, however, are developed only here and there, and for the greater part of the circumference of the stem are absent (Fig. I). This structure is figured from a still larger stem (of $M$. Moorei, F. Muell.) in the Kew Museum.

This is what is usually seen in the lower region of the stem. Higher up, and especially near the apex, the third and fourth rings become more and more indistinct, and finally are no longer recognizable. The first anomalous ring alone persists as a conspicuous zone close to the apex of the stem.

I will now proceed to describe in detail the various tissues which go to make up the stem of this plant.

\section{Structure of the Pith.}

One of the most striking features of the whole structure, and one which is apparent at the first glance, is the presence in the pith of a dense network of vascular bundles, in fact the same phenomenon which occurs in the stem of Encephalartos, but which has been found to be absent in all other genera hitherto described.

If transverse sections are made in any portion of the pith, these bundles will usually be found in oblique or even in longitudinal section, but are scarcely ever cut through in an accurately transverse direction, showing that they do not run as isolated bundles perpendicularly through the tissue of the 
pith; but that, on the contrary, their course lies in almost every direction, owing to the fact that they form part of an anastomosing system whose different branches traverse the length and breadth of the pith. If one of the main branches of this system is transversely cut through, it will be seen to be a bundle similar in size and appearance to one of the girdles of the cortex, consisting of a thick band of xylem and phloem produced by the activity of a cambium. Unlike the bundles of the cortex, however, its xylem and phloem have no regular orientation with regard to the vascular cylinder or the exterior of the stem, but lie, on the contrary, in any direction. The fact is that each branch of this medullary system, whether large or small, follows closely and is accompanied by a branch of a similar anastomosing network of mucilage-canals which traverse the pith in every conceivable direction. It is the mucilage-canal which invariably determines the orientation of the bundle, so that the phloem is always directed towards, and the xylem away from, the canal (Figs. 3, 6-8). It may frequently happen that a canal is accompanied by two bundles, one on either side, which anastomose with each other here and there on their course. But as the mucilage-canal twists and bends about through the pith, the bundle accompanying it appears first on one side of it and then on the other-seeing that it takes a short cut and does not follow every twist and turn of the canal-and in order, therefore, to preserve its orientation, it must necessarily undergo a twisting on its axis, the phloem being always on that side of the bundle nearest the canal (Fig. 3).

As showing how irregular and anomalous is the course of these medullary bundles, Fig. 5 represents a curious involution which very frequently takes place whereby the bundle or a portion of it assumes a perfectly circular course; it may also sometimes be seen entwining a- mucilage-canal in this way. Renault ${ }^{1}$, in his investigations of fossil plants, has figured similar contortions amongst the tracheides of the wood in the fossil genus Cycadoxylon.

1 Structure comparée de quelques tiges de la Flore Carbonifère, Plate I4, I879. 
If transverse sections are made of the pith at the periphery, where it borders on the vascular zone, here and there one of the smaller branches of these medullary bundles may be seen running out, accompanied by its mucilage-canal, through a medullary ray between the segments of the wood. Its xylem and phloem join on in passing to that of the normal ring, while the mucilage-canal passes outward to the cortex to form a connexion with a similar system of secretory tissue in that part of the stem (Fig. 4).

In connexion with the xylem of the bundles, especially the larger ones, there is also very often to be seen what may be called a kind of transfusion-tissue, consisting of small, angular, isodiametric tracheides with bordered pits, running out alone into the tissue of the pith. These are usually connected with the first-formed elements of the bundles.

The proof that the medullary bundles of this plant, as in Encephalartos, form a separate cauline system of the stem, and are in no wise connected, as in Stangeria and others, with the conducting tissue of the peduncles, lies in their origin.

In transverse sections of the pith, taken from a region not far from the apex, mucilage-canals were seen in abundance, but no bundles whatever in connexion with them. A little further down, however, there began to be signs of a distinct differentiation amongst the cells immediately adjoining the mucilage-canal, and more especially on one side of the latter. The cells were much smaller and, therefore, more numerous. Still further down there appeared a difference in the cellwalls, especially in those of the outermost of these small cells, which gradually became thickened and lignified, these elements being evidently on the way to become tracheides; at the same time the innermost cells became further divided up as a preparation for phloem-formation. Eventually, the primary xylem and phloem became fully differentiated, each having respectively the orientation above described for the mature bundles (Figs. 6-8).

Anything of the nature of protoxylem is absent from these bundles, as one would naturally expect in secondary structures. 


\section{Structure of the Vascular Zones.}

As seen in transverse section, the xylem of the normal ring is divided up, as in other Cycads already described, into narrow segments consisting of from one to three or four rows of elements in breadth, these being separated by medullary rays one or more cells broad. These segments of the xylem taper towards their inner margin where they abut on the pith. They appear usually to be arranged in groups with wider medullary rays separating such groups. As the different parts of the xylem, as well as of the phloem, are not all cut through in an equally accurate transverse direction, but are, on the contrary, often very obliquely sectioned, some of the vascular segments must depart considerably from the normal vertical course, and this was seen in longitudinal sections to be the case in nearly every part of the stem.

The phloem, in transverse section, appears to be composed of fairly regular rows, 2-4 cells broad, of sclerenchymatous elements, and of thin-walled small-celled tissue, the whole being divided up into segments, as is the xylem, by the medullary rays. On the outer side are seen the crushed remains of the primary phloem. On the inner side the cambium, forming a conspicuous zone, separates the secondary phloem from the xylem. Large idioblasts or stone-cells occur everywhere scattered about amongst the cells of the rows and in the medullary rays.

The xylem and phloem are of almost equal thickness. They are moreover, when observed under a low power, by no means easy to distinguish the one from the other, the lignified fibrous elements of the phloem being readily mistaken for tracheides.

A radial longitudinal section shows the wood to be of the usual Cycadean character; and owing to the tangentiallycurved course of the tracheidal bands, the appearance is given, in most sections, of alternating zones of tracheides and rayparenchyma. The protoxylem has completely disappeared 
from the vertical strands of wood owing to its obliteration by the expanding parenchyma of the pith. It is only where the xylem of a leaf-trace is curving outwards, as a broad band of tracheides, that the typical spiral and reticulate elements are preserved; as they are in this position, perhaps, somewhat better protected against tension than elsewhere, though even here they are mostly isolated and broken up into fragments.

On the interior vertical face of the wood, where the protoxylem would naturally be sought, are often to be found the peculiar, irregular tracheides, resembling transfusion-tissue, above described as accompanying the medullary bundles.

The tracheides composing the secondary wood have the normal bordered pits on the radial walls. On the tangential walls very minute simple pittings were frequently observed.

Here and there, between the tracheides, are rows, usually one cell in thickness, of parenchyma, but there is only a comparatively small quantity of this present in the wood.

A characteristic feature of the radial section of the wood is the large number of out-bending strands of tracheides which, passing through the medullary rays, are continuous with the girdle leaf-traces of the cortex.

In a radial section of the phloem the greatly-elongated fibres are the most prominent objects. They serve, doubtless, to add strength and durability to a stem so largely built up of parenchymatous tissues. Side by side with these are seen the sieve-tubes, much elongated elements on whose obliquely-extended terminal and lateral walls very numerous sieve-plates of diverse shapes are seen, even without any staining. No callus, however, could be detected after repeated attempts at staining with aniline-blue. This was also the result of Strasburger's ${ }^{1}$ investigation in the case of Cycas, who states that the cambial activity having ceased in this vascular ring, the sieve-tubes have lost their function, and therefore no longer deposit callus on their plates. But 
the fact that in none of the rings could I detect any callusformation seems to point to the conclusion that the growth of the stem as a whole had been arrested; this seems the more probable from the fact that the whole organ was infested in every part, from apex to base, with the mycelium of a Fungus, a condition of things which might tend to materially affect the normal functions of the stem. Indeed, the reason why this stem had been handed over to the Laboratory was that the apex was in a state of decay, and the plant had therefore become worthless for purposes of cultivation. Bordering on the sieve-tubes are extremely narrow long elements which are albuminous cells. Ordinary phloem-parenchyma, consisting of broader, shorter cells, is also present.

Returning once more to the transverse section from the lower part of an adult stem, we find, immediately abutting on the normal vascular ring, a second ring equal, or almost so, in breadth to the first. The inner portion of its wood abuts directly on the outer, first-formed phloem of the normal ring (Fig. 2).

It may be mentioned here that the segments of each of these two successive rings do not always lie evenly parallel one with the other. Occasionally one sees a large, wedgeshaped segment, really appertaining to the second ring, which has become pushed out of line, and lies embedded in a large medullary ray of the normal ring; so that it is at first not quite easy to tell to which of the two rings it really belongs (Fig. I). There is, indeed, especially in the lower region of the stem, great irregularity in the whole structure, which may be partly due to the free play afforded to the expansion of the parenchymatous tissues in a stem whose vascular portion is so loosely compacted.

This first anomalous ring succeeds the normal ring just as has been described for Cycas and Encephalartos; and, at first, one would suppose that, in the plant I am describing, there was no more to be added to this point. But, on a subsequent more minute examination of the region where the phloem of 
the normal ring abuts on the innermost tracheides of the first anomalous ring, an additional anomaly was perceived, which, in previous examinations of similar structures, had been entirely passed over. Here, between the two rings, a tertiary cambium had arisen, whose activity had produced a single small and isolated bundle, the peculiarity of which, however, lay in the fact that the orientation of its parts was reversed, its phloem being directed towards that of the normal ring and its xylem towards that of the anomalous ring (Fig. $9 a v b^{3}$ ).

Owing to the expansion of the phloem-parenchyma of the normal ring, some of the phloem-elements, such as the fibres, were seen lying outside the little bundle, which latter had thus become partially embedded in the phloem, and also, by the pressure of the parenchyma, rather distorted and shapeless. In sections of the same region from other parts of the stem a similar small bundle was observed, but with a different orientation, as it lay sideways, the plane of symmetry of its collateral structure forming a right angle with that of the two rings. In another case it was observed to lie, with the normal orientation, in a medullary ray at the side of the segments, but still in the region between the two rings. But I look upon these last two positions as departures from the normal orientation of the bundle, being irregularities due, probably, to the pressure of the surrounding parenchyma; much the more usual position is the inverted one above described. In other parts of the stem this cambium was seen to be less active than in the cases just described, and to form fewer elements of xylem and phloem, so that the tiny bundles thus formed are scarcely perceptible. Again, where a segment of the first anomalous ring is but feebly developed and but very few xylem- and phloem-elements are formed (for in certain parts of the stem this anomalous zone may be broken up into comparatively small segments), immediately on its inside, only separated from it by a few large parenchymatous cells, is frequently seen a minute bundle, or rather a halfbundle, consisting of two or three radial rows of phloem- 
elements, of which the innermost one or two are seen to be lignified and represent fibres. This probably represents the same formation as the inverted small bundle above described, although, in this case, no xylem has been added by the cambium.

If we now pass outward beyond the first anomalous ring, on its immediate outer limit a third zone is met with, composed of bundles or segments, as above stated, which are very much smaller in size and less closely and compactly arranged than those of the first two rings. This zone constitutes the second definite anomalous ring produced by an extra-fascicular cambium. The segments composing it have the usual wedge-shaped contour, and in many parts of the stem are very irregularly arranged. They often leave the vertical and run in a tangential direction. These remarks apply to the lower region of the stem; in the upper portion no second zone of anomalous thickening is usually distinguishable, and the first ring, as also the normal vascular zone, is much less strongly developed.

In conjunction with the second anomalous ring the same phenomenon of inverted cambial activity occurs, but here in a more easily distinguishable and clearly defined manner. On the inner side of several of the segments, and separated from them by a few layers of parenchyma, appeared a bundle or segment, usually of smaller size, with inverted orientation, so that its xylem was placed directly opposite that of the normally orientated segment in some cases, while in others the bundle lay obliquely and at an angle with the other (Figs. 2, 10). The elements composing these inverted segments are not always so well developed and their walls not so sharply defined as those of the main segments, facts which tend to make them insignificant in appearance and easily passed over. Such a bundle was sometimes represented by only a mere rudiment made up of a few elements. In one or two cases, where the inverted segment lay rather obliquely, it formed an almost continuous zone with the normally orientated segment, thus indicating a tendency towards the formation of a concentric 
bundle. It is worth noting that here and there in the space between an inverted and a normally orientated segment, several of the short, angular tracheides with bordered pits above described as occurring in conjunction with the medullary bundles and the xylem of the principal zone, were seen (Fig. 10); the presence of these added to the remarkable resemblance which the whole structure bore to the concentric cauline bundles in the cortex of Cycas, for here also these curious tracheides occur in the so-called pith. Where fragments of a third anomalous ring occur in the shape of a few scattered bundles, these may also be accompanied by a similar inverted bundle.

This peculiar tertiary cambial formation in connexion with the anomalous zones of secondary thickening in the stem of this plant has not hitherto been observed in the stem of any other genus. I could myself find no trace of a similar structure in connexion with any of the anomalous rings of Cycas media, of which plant I examined a very large stem with about a dozen vascular zones. At the same time, I believe, from a comparison made between the two, that this structure is homologous with that of the concentric cauline 'bundles' so well known to occur in the cortex of Cycas. These latter appeared, in the adult stem which I examined, as tangentially-extended zones, each of which had an orientation, as regards its xylem and phloem, the reverse of that in the other, the central region being filled with the short tracheides already mentioned.

This anomaly in Macrozamia I believe also to be similar in nature to, and homologous with, the well-known structure described by Gregg ${ }^{1}$ in the roots of Cycas Seemanni.

The tranverse section of the stem shows clearly the passage of the leaf-trace bundles through the broad medullary rays from the cortex, traversing the successive vascular rings, to the normal cylinder. They may have connexions during their course with segments of each of the rings, thus establishing

\footnotetext{
1 Anomalous Thickening in the Roots of Cycas Secmanni, Ann. of Bot., Vol. i, 1887 .
} 
between the vascular zones and the leaves a direct system of communication.

The direct connexion existing between the several rings of vascular tissue, apart from that afforded by the leaf-traces, was very clearly seen by the aid of radial sections which exhibited at intervals, especially between the normal and the first anomalous rings, very broad bands of wood and bast connecting the two both in a downward (the more marked of the two) and in an upward direction. Connexions in both directions may sometimes occur in close proximity, which thus give the curious looped appearance shown in Fig. I I, which is a diagrammatic, though accurate, representation of the structure. In this manner, by the continuity of the cambium of the different zones, a perfect communication is established between the various parts of the conducting-tissue of the stem.

It should be mentioned that the curious 'transfusiontracheides,' which have already been several times referred to, constantly occur in considerable numbers (as is also the case in Cycas media) on the inner margin of the anomalous rings. They are of very various shapes, being either quite isodiametric, or oblong, contorted and shapeless, or more elongated and narrower, and having for the most part bordered pits on their walls. Whether they always formed a continuous series or not, as in normal transfusion-tissue, it was difficult to determine, and I did not succeed in so doing, but such is probably the case (Fig. I $2 t$ ).

A tangential section through the wood or the bast exhibits the curious looped structure caused by the bending of the tracheides and fibres in the tangential direction, this being due to the growth and expansion of the medullary rays which traverse these gaps. In each such loop or gap is seen a leaftrace bundle with xylem directed upwards and one or two mucilage-canals (Fig. I3).

\section{StRUCTURE OF THE CORTEX.}

The cortex occupies an area of the stem almost equal in thickness to that of the vascular zone. It is chiefly characterized 


\section{I 4 Worsdell.-Anatomy of Stem of Macrozamia}

by the presence of a large number of leaf-trace bundles and, as in the pith, a network of mucilage-canals whose branches penetrate its tissue in every direction. These canals are often quite filled with cluster-crystals of calcium oxalate. Large stone-cells are of frequent occurrence throughout the cortex. The large number of bundles seen in transverse section of the stem on the inner margin of the cortex (Fig. I $g$ ) represent the inner ends of the girdle leaf-traces as they pass obliquely downwards to join the vascular zone. Their previous course through the cortex from their origin in the leaf-base is identical with that already well known in Cycas and other genera. On emerging from the leaf they pass for a long distance in the tangential direction, often two or three together, close beneath the surface of the stem, gradually, however, bending inwards and downwards towards the centre (Fig. I g). Some, however, follow a more direct route and bend off suddenly in a radial direction after a longer or shorter tangential course and pursue a direct path to the vascular zones (Fig. I 6 lt). These latter, which do not occur in every region of the stem, may be associated together in considerable numbers, varying in size amongst themselves, being branching members of the original single bundle which passed into the stem from one side of the leaf-base. As they bend off in the radial direction they are often seen to arrange themselves in a curious arc, giving the appearance of an imperfect little cylinder of bundles, as seen in tangential section of the cortex. Some of the larger bundles, which run isolated through the cortex, show a distinct tendency towards a concentric structure. The leaf-trace girdles, during their tangential course around the stem, exhibit a rather striking structure from the fact that a large number of the tracheides of their secondary wood have become abnormally developed so as to resemble, in the spiral thickenings which they possess, the ordinary protoxylem. These tracheides are very broad elements, having more than twice the diameter of either the protoxylem-elements themselves or those of the rest of the secondary wood. They are, moreover, like those of 
the protoxylem, more or less disorganized (Figs. I4, I $5 s p x^{2}$ ). The normal part of the secondary wood only attains a comparatively small development, and its tracheides have the ordinary bordered pits (Figs. I4, I $5 n x^{2}$ ).

The explanation of the peculiar structure of these bundles lies in the fact that, from the direction of their course in the cortex, they would inevitably be submitted to an extreme tension in the tangential direction, so that an adaptation in a portion of the secondary wood, in the form of greater extensibility in the walls of the tracheides, became an imperative necessity, and thus we find the curious appearance in the secondary wood of tracheides with dense spiral thickenings. These bundles are orientated so that the xylem and phloem are directed towards the inside and the outside of the stem respectively. In many cases the outward course of the bundles was interrupted and cut short by the periderm. It is a fact worth noting that, as soon as the bundle leaves the tangential and assumes a more or less radial course, this abnormality in their secondary wood becomes very much less marked and tends to disappear altogether.

Uniting the various girdles in different regions of the cortex are 'radial connexions,' consisting of bundles equal in size to those of the girdles, and often fusing with them by means of a curious network of elements which are sometimes quite contorted and involuted.

On the outer limit of the cortex, the periderm forms a conspicuous layer, recognizable with the naked eye as a narrow white zone with an extremely irregular, sinuous course. It consists, on its outer side, of a layer of crushed cork-cells, and on its inner side, of a thick zone of phelloderm, built up of large square or variously-angled idioblasts or stone-cells, alternating with much smaller, thin-walled, colourless cells. The cells of this zone were seen to be arranged in radial rows continuous with those of the cork-layer on the outside. The periderm by successive layers cuts off, firstly, bit by bit of the leaf-bases, as shown in Fig. I, where the dark lines $(p d)$ represent this tissue, the deeply-shaded portions 
between them being the dead, brown, parenchymatous tissue of the leaf-base, in the still living portion of which latter the leaf-traces are seen passing inwards to the cortex. After the leaf-bases have been disposed of, the periderm continues to eat its way into the cortex. Its successive layers arise in a very irregular manner, and often in the phelloderm of the older one (Fig. 17). There is no clean excision of the tissues along a definite line, as in Zamia, whereby a smooth even bark is obtained; but the outer surface of the stem, owing to this irregular sinuous formation of the periderm, is left very rough and jagged, consisting either of the remains of the leaf-bases or of dead portions of the cortex.

Owing to the periderm-formation it is difficult, in an old stem, always to obtain a proper clue as to the course of many of the leaf-traces in the extreme outer part of the cortex, as this region is often entirely cut away.

\section{SUMMARY.}

The most noteworthy characters exhibited by the anatomical structure of the stem of Macrozamia are the following :-

I. The well-developed medullary system of bundles, which has a distinct adventitious origin of its own and is not directly continuous with the primary leaf-trace system, but only forms secondary anastomoses with it, being connected, by means of the medullary rays, with the various parts of the vascular ring. The curious contortions and involutions which some of the bundles of the pith undergo are also to be noted.

2. The anomalous zones of secondary thickening which, to the number of two or three, surround the normal cylinder. Of these the innermost is the best developed, being as thick as the normal ring upon which it immediately borders, and is the only one quite readily distinguishable with the naked eye on the cut surface of a stem. The second and third rings are much more feebly developed, and, in the upper part of the stem, often entirely absent. They are usually composed 
of small, scattered segments, consisting of equal parts of xylem and phloem, and either abutting directly on the phloem of the first anomalous ring, or separated therefrom by a few layers of parenchyma.

3. The presence of a tertiary cambium which, arising in isolated places in the parenchyma either between the normal and the first anomalous ring, or between two anomalous rings, forms wood and bast with inverted orientation, such that its xylem is usually directly opposite that of one of the segments of an anomalous ring. This orientation of the bundles, especially in those near the normal ring, is, however, subject to the variations described in the foregoing pages, as is also the amount of tissue formed by this cambium.

4. The irregularity and displacements of many portions of the vascular tissue, owing to the great expansion of the parenchyma and the medullary rays between the various segments composing the rings.

The occurrence of the anomalous zones of thickening and of a tertiary cambium producing bundles with inverted orientation in this stem, can scarcely be passed over with a bare statement of the facts. I have been much struck with the appearance of these structures, especially after comparing them with anomalies in the stem of Cycas, and have therefore deemed it worth while to put forward a few considerations with regard to them, before drawing this paper to a close.

It appears to my mind highly probable that these structures have a phylogenetic and not a merely physiological significance. I would emphasize the great similarity existing between the structure, such as that represented in Fig. 12, and that of a concentric cauline bundle of Cycas. There are the same 'transfusion-tracheides' between the two oppositely-orientated strands of vascular tissue, a fact which seems to show that the parenchyma separating the two strands in Macrozamia is identical with the so-called pith of the cortical bundles in Cycas.

The whole structure, both of the anomalous zones and the tertiary cambiums, recalls strongly that of the stem of the 
Medullosae ${ }^{1}$, a fossil group with many Cycadean affinities; but it would be rash and premature to suggest here a homology between the two.

From these considerations I have been led to give the following provisional suggestion, viz.-

That the anomalous structures in Cycadean stems, and especially those in the stem of Macrozamia, are remnants of some ancient structure once common to a large group of plants. That this structure consisted of rings or layers of concentric vascular strands. That, as time went on, and greater specialization in the conducting-tissues arose, and a need for the formation of a larger amount of this tissue became urgent, the cambium of the inner portion of each such concentric strand gradually became less and less functional, that of the outer portion, on the contrary, more and more active, so that a much larger quantity of wood and bast became formed on the outer side of each strand than on the inner side, for this was the surest and best means of economizing both space and expenditure in the building up of an efficient conducting tissue for the stem.

The result is, finally, the structure, as we at present know it, in the stem of Cycas, Encephalartos, and Macrozamia. Some evidence for its origin lies in the relics of the inner cambium of the concentric strands in the vascular zones of Macrozamia ; in the 'transfusion-tracheides' constantly found on the inner margin of every ring both of Cycas and Macrozamia; and in the presence of rings of concentric bundles, still preserving the old structure, in the cortex of Cycas.

5. The presence of leaf-traces in the cortex which run directly inward to the vascular rings after a very short tangential course, without describing the curves characteristic of the girdles in this and other Cycads.

6. The structure of the girdles during their tangential

1 Göppert u. Stenzel, 'Die Medulloseae, eine neue Gruppe der fossilen Cycadeen;' Palaeontographia, Vol. 28, 188I. Sterzel u. Weber, 'Beiträge zur Kenntniss der Medulloseae,' XIII. Bericht der Naturwissenschaftlichen Gesellschaft zu Chemnitz, 1893-1896. 
course, in which a large number of the tracheides of the secondary wood become spirally thickened, thus participating in the function of the protoxylem.

7. The structure and mode of action of the periderm at the periphery of the cortex, of which the phelloderm is largely composed of stone-cells, and produces subsequently a second phellogen in its midst.

It will thus be seen that, although there are many characters which Macrozamia has in common with Cycas and other genera already described, this genus possesses characteristic anatomical features which up to this date have not been noticed in the literature dealing with other members of this important order.

In conclusion, I must express my thanks to Dr. D. H. Scott for the help and many valuable suggestions which he has given me.

\section{EXPLANATION OF FIGURES IN PLATES XXVII AND XXVIII.}

Illustrating Mr. Worsdell's paper on Macrozamia.

The following are the abbreviations used in the lettering of the figures: $p$, pith ; $m b$, medullary bundle; $x$, xylem; $p h$, phloem; $n r$, normal ring; $n p h$, normal phloem; $a r^{1}$, first anomalous ring; $a r^{2}$, second anomalous ring; $v b^{4}$, bundles formed by a fourth cambium; $a x^{1}$, xylem of first anomalous ring; $a v b^{3}$, bundle formed by tertiary cambium ; $m c$, mucilage-canal ; $t$, 'transfusiontracheides'; $m r$, medullary ray; $c t$, cortex; $g$, girdle leaf-trace; $l b$, leaf-base; $p d$, periderm; $c$, cork; $p d m$, phelloderm; $p g n$, phellogen; $p x$, protoxylem ; $s p x^{2}$, spirally-thickened tracheides of the secondary wood; $n x^{2}$, normal tracheides of the secondary wood; $l t$, leaf-trace.

Fig. I. Segment from a transverse section of a stem of Macrozamia Moorei, F. Muell., in the Kew Museum, showing the general arrangement of the tissues from the pith to the leaf-bases. Natural size.

Fig. 2. Transverse section of a portion of a similar stem of M. Fraseri, Miq., preserved in spirit, showing segments of the anomalous zones of secondary thickening. $\times$ I 5 .

Fig. 3. Medullary bundle following a mucilage-canal, showing especially well the orientation of the former in the different parts of its course. Diagrammatic. 
Fig. 4. Transverse section of a portion of the periphery of the pith where a medullary bundle is in the act of passing out through the normal ring. $\times 30$.

Fig. 5. An involuted portion of a medullary bundle. $\times 30$.

Fig. 6-8. Transverse sections of incipient stages in the development of medullary bundles. Figs. 6 and $8, \times 85$; Fig. $7, \times 45$. For Fig. 8 see Pl. XXVIII.

Fig. 9. Transverse section of the region between the normal and the first anomalous ring, showing a small bundle with inverted orientation. $\times 45$.

Fig. I०. Transverse section of a segment of the second anomalous ring, with a small inverted bundle on its inner side; 'transfusion-tracheides' between the two bundles. Slightly diagrammatic. $\times 30$.

Fig. II. Diagram of the normal and the first anomalous zone in longitudinal section, showing the oblique connexions between the two.

Fig. I2. Longitudinal section passing through the extreme outer limit of the normal zone and the extreme inner limit of the first anomalous zone, showing ' transfusion-tracheides' between the two.

Fig. I3. Diagram of a tangential section of part of the xylem showing the local curved course of the tracheides owing to the expansion of the medullary rays. The leaf-traces in their outward course are seen in transverse section.

Fig. I4. Transverse section of a girdle leaf-trace during its tangential course through the cortex. $\times 60$.

Fig. I5. Longitudinal section of the same. $\times 45$.

Fig. I6. Diagram to illustrate the direct radial course of some of the leaf-trace bundles through the cortex. For this figure see Pl. XXVII.

Fig. 17. Section through an outermost portion of the cortex, showing the mode in which a new periderm-layer arises within the phelloderm of the old one. $\times 30$. 


\section{Annals of Botany}

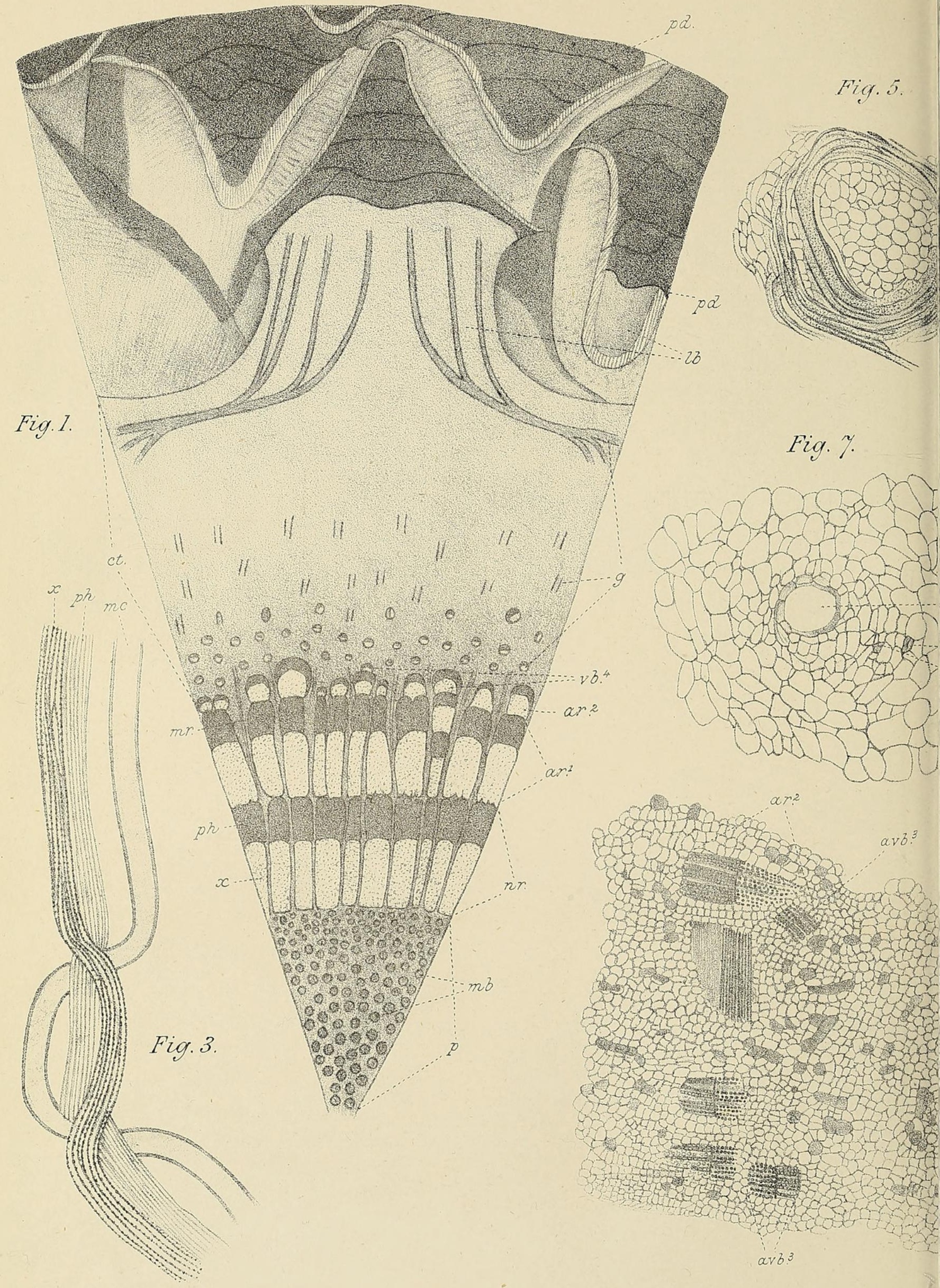

W. C.W. del 


\section{Annals of Botany}

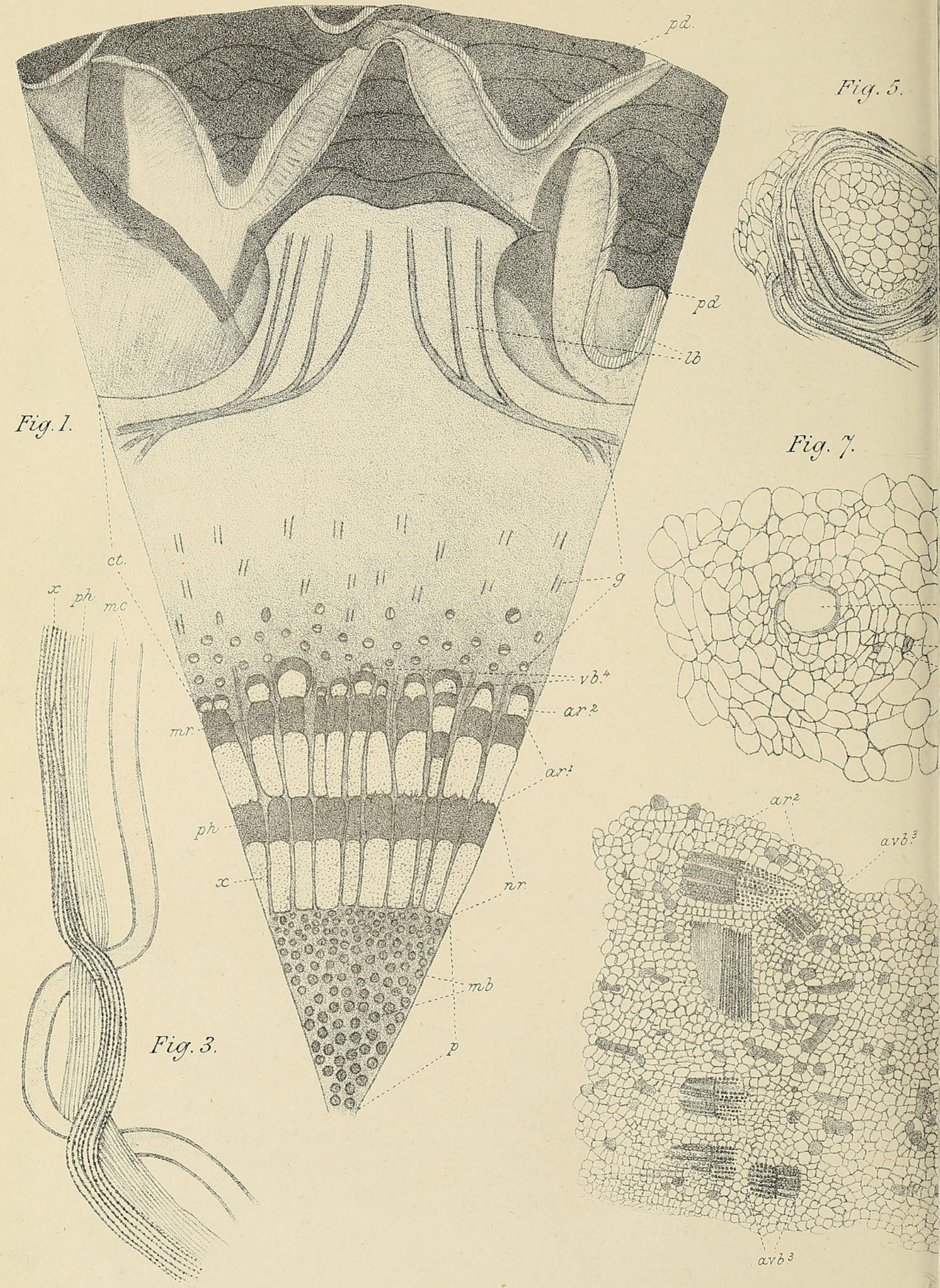

W. C.W. del 

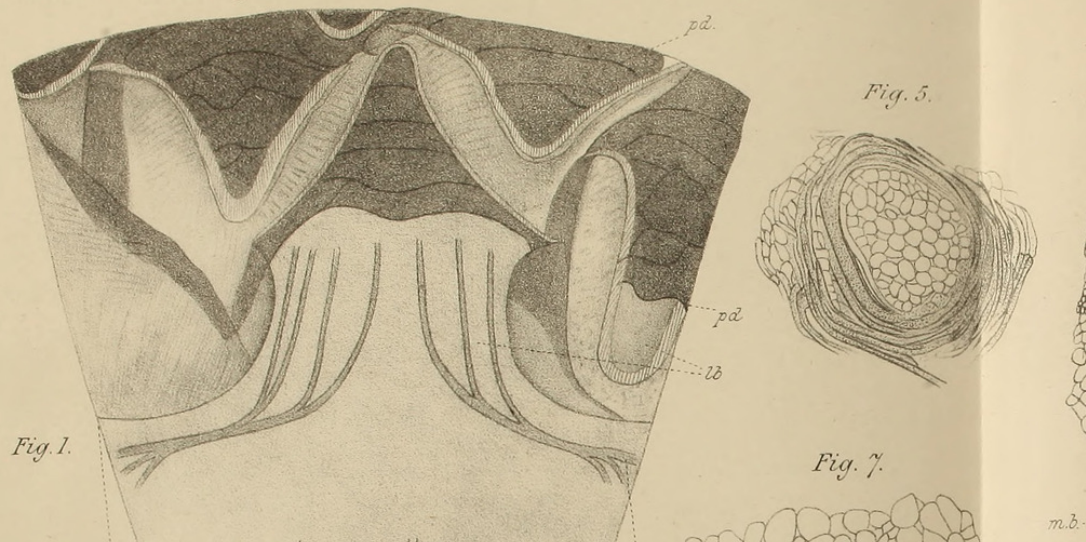

Fig. \%.

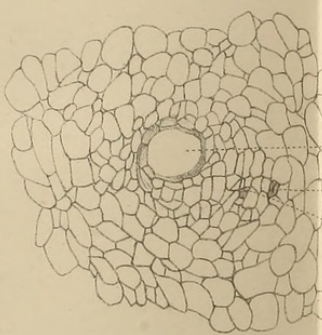

ar:
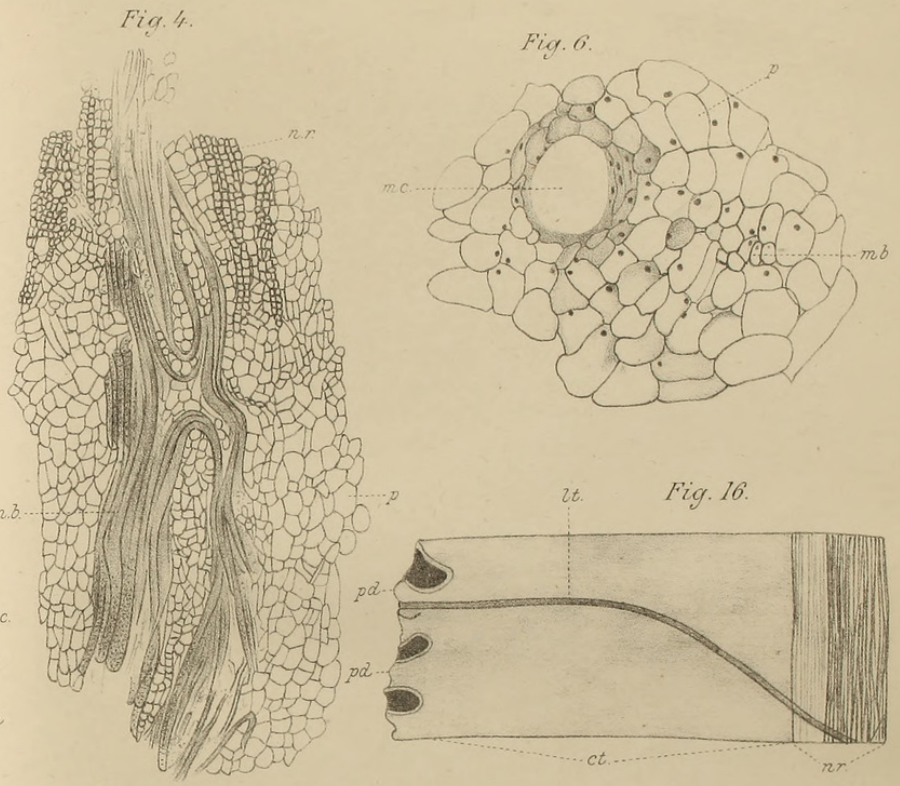

Fig. 2.

Q

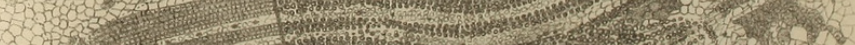

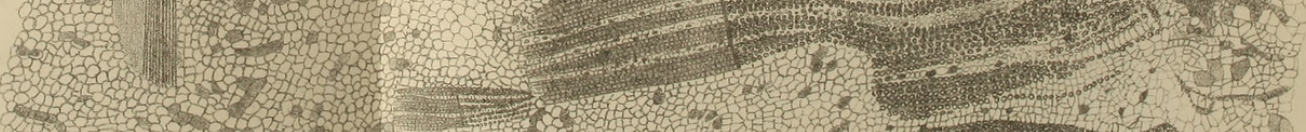

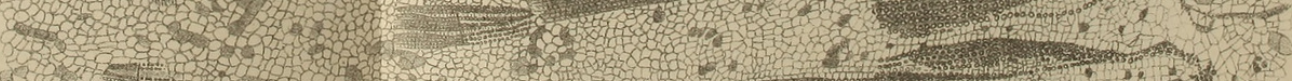

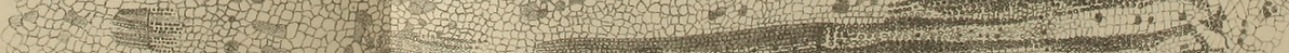
M.

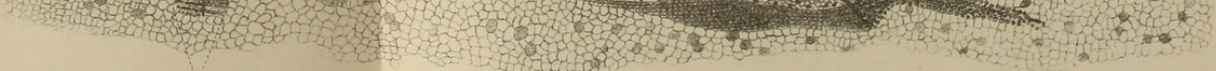
$a \vee b^{3}$ 


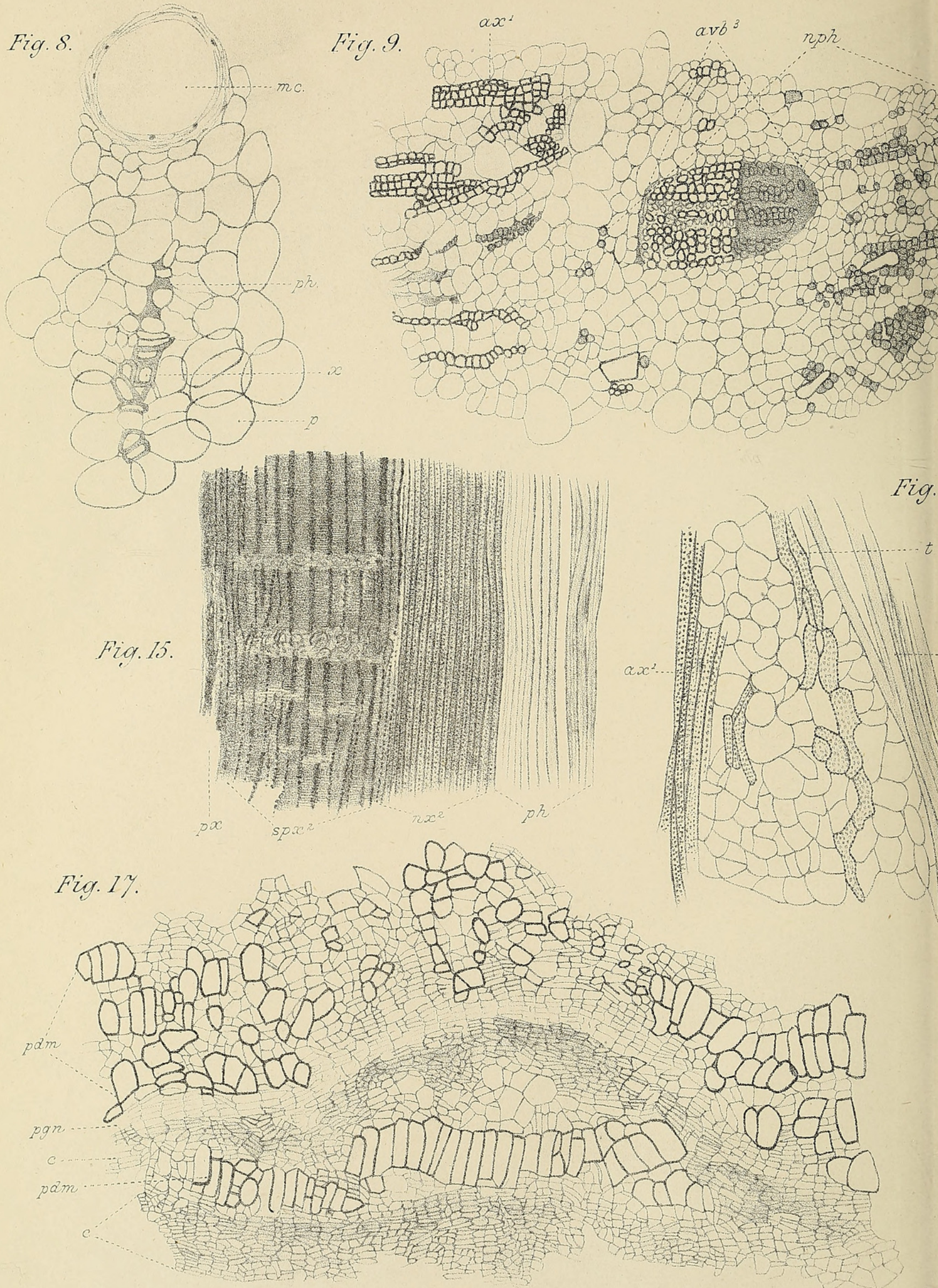



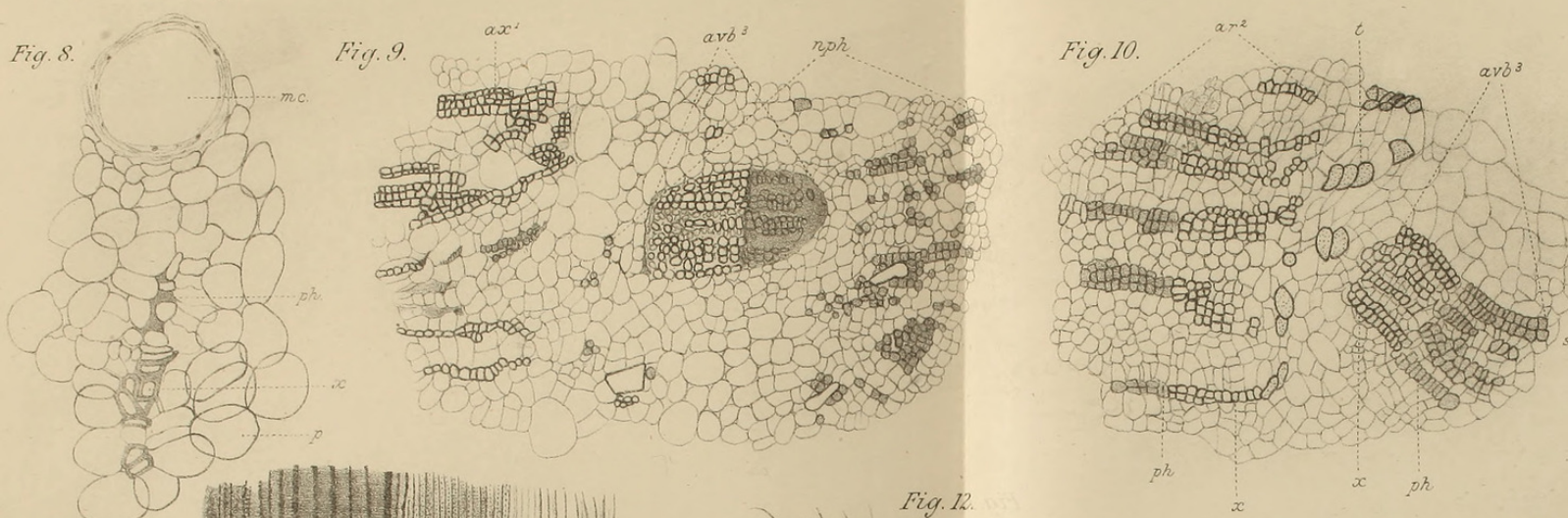

Fig. 14
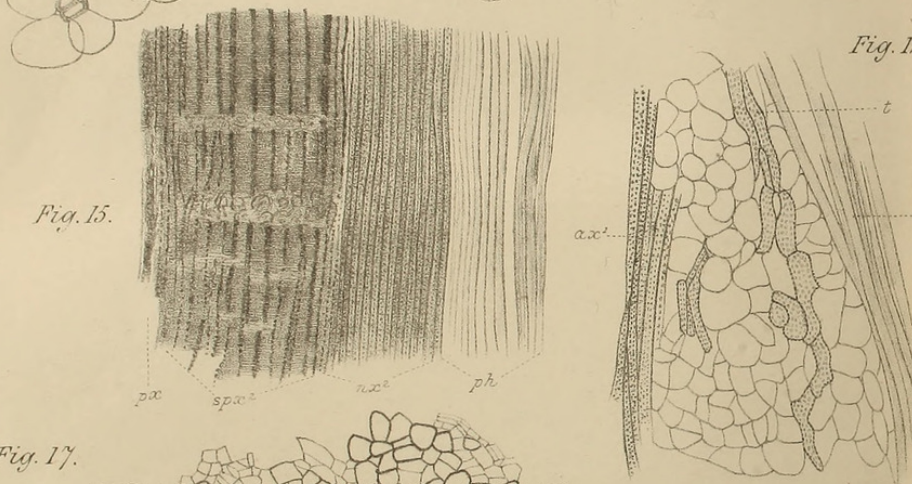

Fig. 1\%.

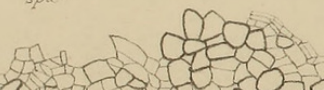

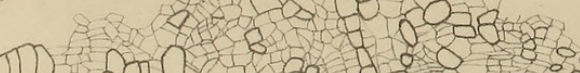

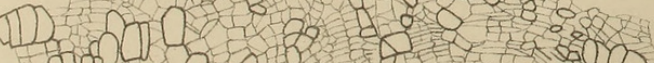

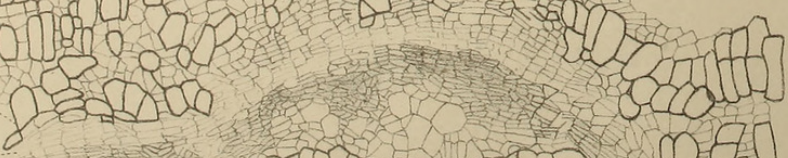
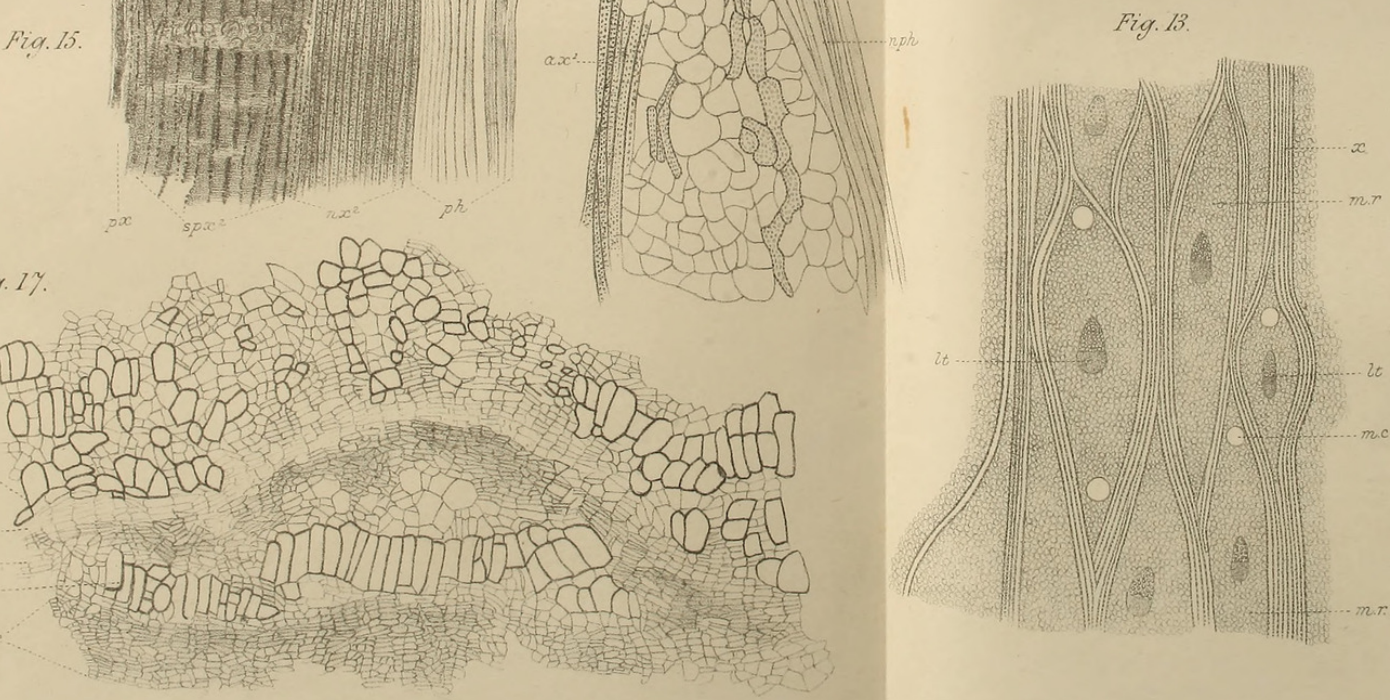

Fig. II.

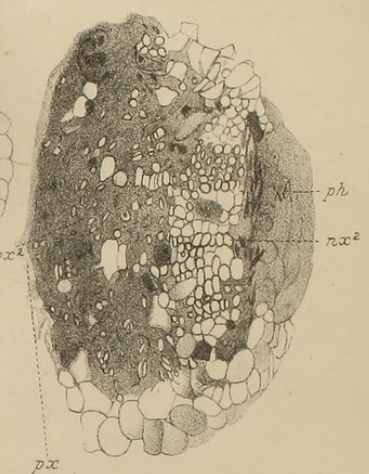

$p x$

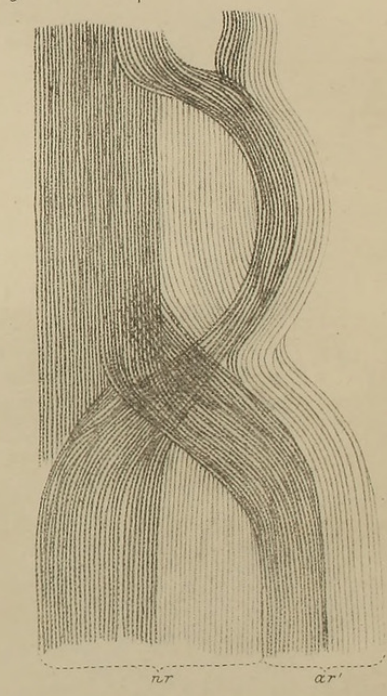

University Press, 0xford

WORSDELL. - ON MACROZAMIA 


\section{$2 \mathrm{BHL}$ Biodiversity Heritage Library}

Worsdell, Wilson Crosfield. 1896. "The anatomy of the stem of Macrozamia compared with that of other genera of Cycadeae." Annals of botany 10 , 601-620. https://doi.org/10.1093/oxfordjournals.aob.a088628.

View This Item Online: https://www.biodiversitylibrary.org/item/235772

DOI: https://doi.org/10.1093/oxfordjournals.aob.a088628

Permalink: https://www.biodiversitylibrary.org/partpdf/318440

\section{Holding Institution}

Smithsonian Libraries

\section{Sponsored by}

Biodiversity Heritage Library

\section{Copyright \& Reuse}

Copyright Status: Not in copyright. The BHL knows of no copyright restrictions on this item.

This document was created from content at the Biodiversity Heritage Library, the world's largest open access digital library for biodiversity literature and archives. Visit BHL at https://www.biodiversitylibrary.org. 